\title{
IMPLEMENTATION OF A SUSTAINABLE LOGISTIC SYSTEM MODEL FOR THE COMMUNAL WASTE COLLECTION IN THE MUNICIPALITY OF BITOLA (MACEDONIA)
}

Ivo DUKOSKI * and Nikolche TALEVSKI *

* University St. Kliment Ohridski Bitola, Technical Faculty Bitola, Ivo lola ribar b. b. Bitola, Macedonia,divo@t-home.mk

** University St. Kliment Ohridski Bitola, Technical Faculty Bitola Ivo lola ribar b. b. Bitola, Macedonia, postdiplomec@yahoo.com

DOI: 10.1515/trser-2015-0010

KEYWORDS: sustainable logistic model, Municipality of Bitola, Macedonia, communal waste.

\section{ABSTRACT}

The purpose of this paper aims for collection, transport and depositing of the communal waste in the Municipality of Bitola. The justification of another systematic approach toward the communal waste in the Municipality of Bitola is also represented.

There are many benefits of the implementation of this kind of sustainable logistic model system for collection of the communal waste in the Municipality of Bitola. It was summarized that the benefits that would be obtained lead to improvement of the living conditions, and with that the implementation of this model would be justified completely.

RESUMEN: Implementación de un modelo logístico de sustentabilidad en un sistema de recolección de desperdicios comunitarios en el municipio de Bitola (Macedonia).

En este trabajo se expone el problema, el sujeto y los objetivos de la recolección, transporte y reubicación de desperdicios comunitarios en el municipio de Bitola. Asimismo, se plantea un enfoque sistémático para abordar el problema de los desperdicios comunitarios en ese municipio.

Se esperan obtener considerables beneficios con la implementación de un modelo logístico de sustentabilidad aplicado a la recolección de desperdicios comunitarios en el municipio de Bitola. Los beneficios que se obtendrían de este sistema darían lugar a un mejoramiento en la calidad de vida de la comunidad, lo cual justifica sobradamente el uso del modelo.

REZUMAT: Implementarea unui model logistic sustenabil pentru sistemul de colectare a deșeurilor comunale în Municipiul Bitola (Macedonia).

În acest articol este prezentată problema, subiectul și obiectivele în ceea ce privește colectarea, transportul și depozitarea deșeurilor comunale în Municipiul Bitola. De asemenea, este prezentată motivația alegerii unui alt sistem de abordare a problemei deșeurilor comunale din Bitola.

Sunt prezentate beneficiile implementării acestui tip de model logistic sustenabil pentru colectarea deșeurilor comunale din Bitola. Pe scurt, beneficiile obținute duc la îmbunătățirea condițiilor de viață și astfel punerea în aplicare a acestui model este justificată. 


\section{INTRODUCTION}

Basic preconditions of each state must provide good living conditions for the citizens. The aspects that contribute to regular decision making are various. One of these aspects that contributes to that is the logistic aspect. The communal logistics also contributes to all functional aspects that compound certain systems.

In this paper, the implementation in the next years of the sustainable logistic system model for the communal waste collection in the Municipality of Bitola is presented. According to that model, this paper itself would represent one reality about the Municipality of Bitola and for the appearance of the communal waste. At the same time, that would allow us to conclude the unambiguously resulted benefits for the citizens and the enterprise of the selection, collection, transport and depositing of the communal waste in the Municipality.

The main drive about the implementation of the sustainable logistic system model for the communal waste collection in the Municipality of Bitola is its uniqueness. As a confirmation of its uniqueness, we shall clearly present real data about the Municipality of Bitola and the way of communal waste collection.

Theoretically, in the Republic of Macedonia it has not yet been studied; additionally, the logistic aspect of collection, selection, transport and depositing of the communal waste has practically not been applied. It is assumed that every man generates different kinds of waste daily and it is obvious that this phenomenon deserves adequate treatment.

According to the last census in 2002, there are 86,408 citizens living in Bitola (Talevski, 2010) and with the new territorial division of 2004, the rural municipalities of Bistrica, Kukurechani and Capari are also added to this figure which increases the number of citizens with an additional 15 percent. This information is represented in table 1.

Table 1: Data regarding the population numbers, households and apartments in the Municipality of Bitola with additional 65 villages according to the territorial division of 2004.

\begin{tabular}{|c|c|c|c|}
\hline $\begin{array}{c}\text { Bitola } \\
\text { Municipality }\end{array}$ & $\begin{array}{c}\text { Total } \\
\text { population }\end{array}$ & Households & $\begin{array}{c}\text { Apartments } \\
\text { (all types) }\end{array}$ \\
\hline Bitola population & 86,408 & 26,387 & 33,232 \\
\hline City of Bitola & 74,550 & 23,010 & 28,155 \\
\hline 65 villages & 11,858 & 3,377 & 5,077 \\
\hline
\end{tabular}

\section{MATERIALS AND METHODS}

Based on the results about the Republic of Macedonia, it is defined that the daily production of communal waste/citizen in Republic of Macedonia (Dukoski, 2005), is:

- $0.7 \mathrm{~kg} /$ day for urban environments (where $60 \%$ of the total population lives);

- $0.5 \mathrm{~kg} /$ day for rural environments (where $60 \%$ of the total population lives).

In other words, annual production of communal waste in Republic of Macedonia amounts 470,000 tones, out of which 322,000 tones are disposed at municipal waste piles, and 148,000 tones in the rural areas.

Acording to the data, collected from the services of the enterprise - Komunalec of Bitola (2005), the quantities of collected and transported communal waste for the Municipality of Bitola ranges from 36,000 to 40,000 tones of annual waste that is disposed on a waste pile situated at 17 kilometers away from the town (Dukoski, 2001; Dukoski and Talevski, 2011). The communal waste is collected in a non-systematic way that financially burdens the enterprise itself and also lowers the service satisfaction level of citizens. The data clearly defines the problem of the research. 
The study revealed the real issues which are confronting the citizens. The activities for the collection, transport, and disposing of the communal waste at a pile, identifies in detail the complete process of great importance logistic actions with its characteristics and parameters that directly or indirectly influence the efficiency of the system organized in this way. The researched subject of the contemporary technological processes and treatments of organized collection, selection, and transport of the communal waste to the waste pile, and with its implementation, would obtain effective and sustainable logistic system models for collection of the communal waste in the Municipality of Bitola. This sustainable logistic model with all of its characteristics, shapes and phases of its creation is presented in figure 1.

The main aim of this paper's research is the inadequate implementation of sustainable logistic system models for the communal waste collection in the Municipality of Bitola.

The aims of the research are based on the following facts: with the help of the scientific methods we prove that the application of the measures and decisions of collection, transport and disposal of the communal waste, it could successfully identify, solve and implement the logistic model of sustainable systems for the communal waste collection in the Municipality of Bitola, qualitatively selected measures for the communal waste collection improvement in the Municipality of Bitola and the introduction of the contemporary technological ways and treatment of this phenomenon, and successfulness in the functionality of this activity in the town.

\section{RESULTS AND DISCUSSION \\ Justification of the implementation of the sustainable logistic system model for the comunal waste collection in the Municipality of Bitola}

This paper with its recognitions and views should be used as an example about the correct approach with the phenomenon of the communal waste and that is:

- its selection (minimizing the quantities of the communal waste at every place);

- collecting the previously selected (separated communal waste);

- transport of various types of communal waste (plastic, glass and paper communal waste to process, and the rest of the communal waste to the waste pile);

- contemporary depositing (with the possibility of applying certain technologies for other purposes).

Findings that are presented in this paper could also serve to reduce expenses of the Komunalec enterprise of Bitola and also the income increase by a different approach to work.

The sustainable logistic system model for the communal waste collection in the Municipality of Bitola itself has many elements of improvement, also for the users of the service and for the citizens of the Municipality of Bitola. The benefit of the citizens is imperative for such systematic approaches toward the communal waste that in all justifies the efforts of this paper.

Great work that is applied in one Municipality should always be justified. It is known that the introduction of any innovation is an expenditure that burdens the citizens, and it is obvious that it should be worth it, but first of all it needs to be applicable. The sustainable logistic system model for the communal waste collection in the Municipality of Bitola also should have to be justified and meet certain requirements of the citizens. Therefore, the justification of its introduction should be represented through the benefits that the Komunalec enterprise of Bitola would have, as well as the benefits that the citizens of the Municipality of Bitola would receive. 


\section{Benefits of the Komunalek enterprise of Bitola}

The benefits for introducing the sustainable logistic system model for the communal waste collection in Bitola and for the enterprise Komunalec of Bitola would be:

- $\quad$ introduction of contemporary way of selected communal waste collection;

- $\quad$ reduction of tours to the waste pile (at least for $30 \%$ );

- improvement of the employees' work conditions at field and in the enterprise itself;

- creation of possibilities for activity enlargement and opportunites for new jobs.

We concluded that the introduction of the sustainable logistic system model for the communal waste collection in the Municipality of Bitola for the Komunalec enterprise would lead to positive economic benefits.

\section{Benefits for the citizens of Bitola}

Benefits for the introduction of the sustainable logistic system model for the communal waste collection in the Municipality of Bitola that would benefit the citizens of the Municipality of Bitola are as follows:

- improving the living conditions for the locals;

- the increasing number of checkpoints for picking up the communal waste of the households;

- $\quad$ reducing the cost for the communal waste pick up;

- economical benefits resulted from the selective collection of the plastic, glass, paper and other communal waste.

The introduction of the sustainable logistic system model for collecting the communal waste in the Municipality of Bitola for the citizens of the Municipality of Bitola would lead to a modern update for cultural and contemporary life.

\section{Common benefits}

From the quoted benefits of the sustainable logistic system model for the communal waste collection in the Municipality of Bitola and also from the systematic approach towards the phenomenon of the communal waste, from ecological, economical and traffic aspect, the justification would be complete, positive and applicable.

Therefore, it could be stated that the sustainable logistic system model for the communal waste collection in the Municipality of Bitola is justified.

Implementation of the sustainable logistic system model for the communal waste collection in the Municipality of Bitola

The implementation represents a flexible approach in the development of the superstructure product in ways that should meet the required needs and necessities of the enterprise (Dukoski, 2001). Concretely, implementation of the sustainable logistic system model for the communal waste collection in the Municipality of Bitola would be complete only with real and commonly accepted application in the every day citizens' activities of the Municipality of Bitola, and also the employees of the Komunalec enterprise of Bitola. In this paper, the implementation refers on the sustainable logistic system model for the communal waste collection in the Municipality of Bitola.

Also the way it should be implemented will be represented in figure 1 . The algorithm for implementing the sustainable logistic system model for the communal waste collection in the Municipality of Bitola with WHAT is necessary (the needs), WHEN and WHERE is necessary (movement, scope, road, and place) all with purpose HOW to implement (with which methods, people and equipment). 


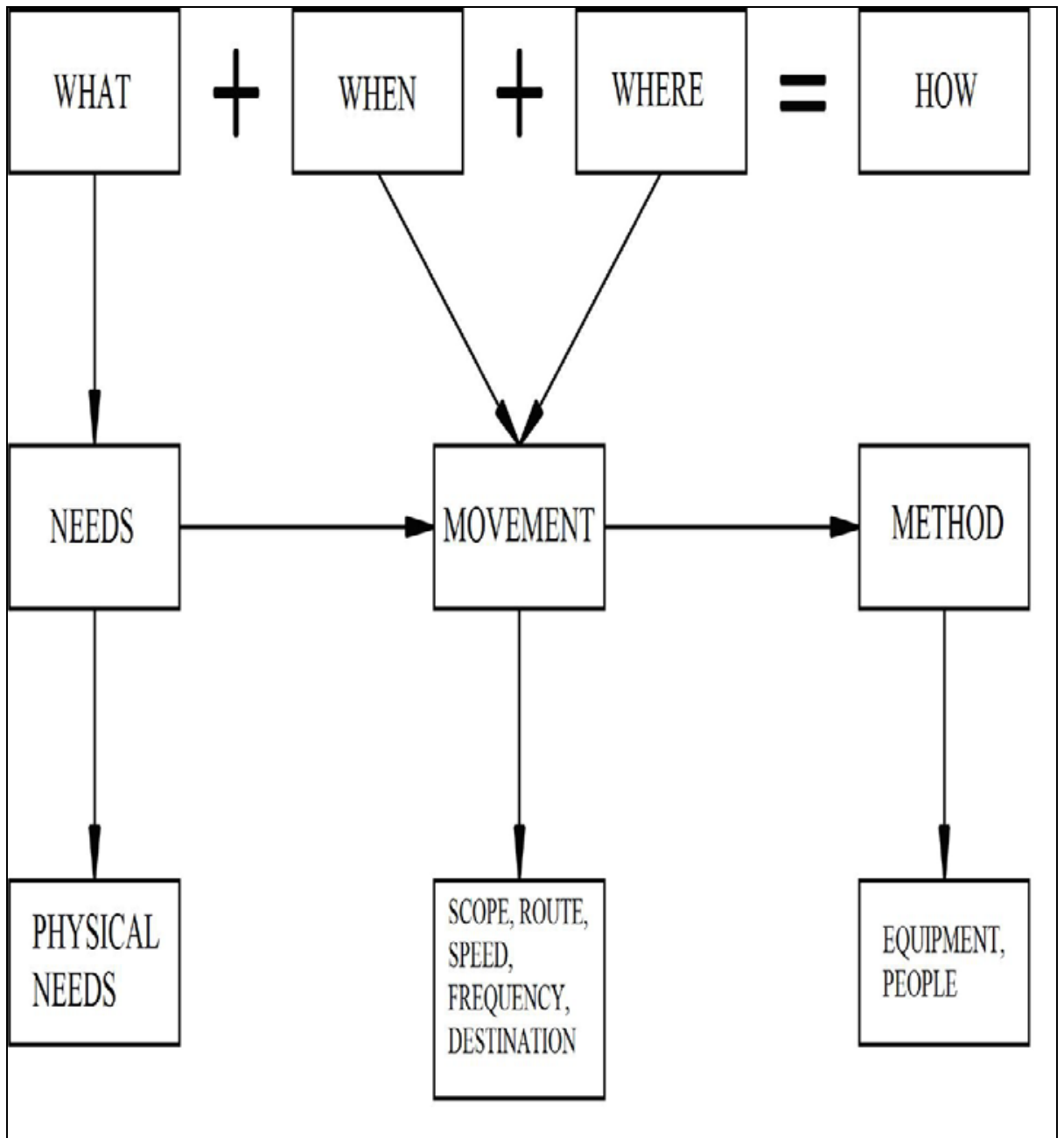

Figure 1: Implementation of the sustainable logistic system model algorithm for the communal waste collection in the Municipality of Bitola.

\section{CONCLUSIONS}

The benefit of this approach is that the subscribers are telling their requests, so the enterprises and the authorities realize that it is a good base for qualitative solutions.

The two way communication is the main base for future investments in this field of interest.

All the elements that make the phenomenon, selection, collection, transport and depositing of the communal waste could come to approval by the subscribers, employees and future investors only by two ways.

This work approach requires adequately implemented systems for the communal waste collection that would be one base for the aimed future steps with respect of WHAT + WHEN + WHERE $=$ HOW principles. 


\section{REFERENCES}

1. Dukoski I., 2001 - Maintenance of the motor vehicles - Logistics, Technical Faculty of Bitola, Bitola, Republic of Macedonia.

2. Dukoski I., 2005 - Logistic systems, written lectures of post graduate scientific studies, Technical Faculty of Bitola, Republic of Macedonia.

3. Dukoski I. and Talevski N., 2011 - Management with the communal waste in the Municipality of Bitola, Code of Technical Faculty, University St. Kliment Ohridski, Bitola, Republic of Macedonia.

4. Talevski N., 2010 - Sustainable logistic model of system for collection of the communal waste in the Municipality of Bitola, MSc Thesis, Technical Faculty of Bitola, Republic of Macedonia.

5. www.stat.gov.mk

6. www.mzspp.gov.mk

7. www.komunalecbt.com.mk/main.html 